\title{
The Implementation of Peer Teaching Method to Increase of Student Competence in Drawing Faces
}

\author{
Desy Tri Inayah ${ }^{1}$, Endang Wani Karyaningsih ${ }^{2}$, Nasrun Baldah ${ }^{3}$, Chytra Mahanani ${ }^{4}$ \\ Department of PKK, Sarjanawiyata Tamansiswa University-Yogyakarta ${ }^{1,2,4}$ \\ Department of Management, Pelita Bangsa University-Bekasi, Indonesia ${ }^{3}$ \\ desytri@ustjogja.ac.id ${ }^{1}$, endang.karyaningsih@ustjogja.ac.id ${ }^{2}$, nasrun.baldah@pelitabangsa.ac.id ${ }^{3}$, \\ chytra.mahanani@ustjogja.ac.id
}

\begin{abstract}
This study focuses on the application of peer teaching-learning methods and the improvement of student learning competencies. The method was used Classroom Action Research (CAR) refers to Kemmis and Taggart, which includes planning, action and observation, and reflection. Data collection by using observation, performance tests, multiple-choice tests, and field notes. The test results showed that the implementation of peer teaching-learning methods included: introduction, main activities, and closing. Furthermore, the increase in learning competence in the pre and post cycle shows a value of $60.6 \%$ and $87.9 \%$. In the Second cycle, competence reaches $100 \%$, or all students pass the KKM score with an increase of $12.1 \%$. Finally, the application of peer teachinglearning methods can improve student learning competencies.
\end{abstract}

Keywords: CAR, competencies, drawing, peer teaching

\section{Introduction}

The teaching and learning process is an activity to carry out curricula in schools or educational institutions to achieve educational goals that have been set. One of the learning objectives is to improve students' learning competencies. Competence is a combination of knowledge, skills, values, and attitudes reflected in thinking and acting habits. Learning competence is divided into three domains, namely cognitive domain, affective domain, and psychomotor domain.

Learning is said to be successful if it can reach three domains of competence that exist in students. The learning process's quality is strongly influenced by the learning component of teachers, students, lesson content, lesson objectives, learning methods, learning media, and evaluation. Learning is said to be successful if a teacher can apply the seven components of learning appropriately in the learning process; this will undoubtedly impact student learning competency values.

One component of learning is the use of methods. The method is one component of learning that is very important; if the selection of learning methods used is not right, it will affect student learning competency values. Nowadays, teachers use many learning methods to create an effective, conducive, and enjoyable learning atmosphere for teachers and students. Peer Teaching learning method is a method that facilitates students with different abilities. Refer to [4] reported that peer teaching is an activity that encourages learning. Students who have more responsiveness to the material being studied can show their care and responsibility towards their peers.

The students can actualize their ability to be more caring for their peers who are less able and jointly responsible for learning, and foster self-confidence. Assistance provided by peers, in 
general, can give better results. The relationship between students feels closer than the relationship between students and teachers.

\section{Literature Review}

\subsection{Action Research}

One of the objectives of classroom action research is to help teachers and education personnel overcome education and learning problems in the classroom. In [1], action research can be used as an alternative if you want to achieve change on a large scale. The collaborative research is a challenge when wanting to achieve change on a large scale [2]. Classroom action research can develop teacher confidence, explore effectively, and more conducive classroom [3] with classroom action research being able to control the classroom atmosphere more conducive, so that both teachers and students are more enthusiastic in the learning process.

The purpose of CAR are following (1) improve and enhance the quality, content, input, processes, educational outcomes, and learning at school; (2) help teachers and education personnel overcome the problems of education and learning in class; (3) improve the ability and professional services of teachers and education staff; (4) develop an academic culture in the school environment; Further, it is to improve and develop teachers and education personnel; (6) Enhance professional collaboration between teachers and education personnel [11]. The action research conducted by [10] managed to prove that the learning that was carried out could have a positive impact both for teachers, students, and school institutions.

\subsection{Peer Teaching}

The objective of the peer-teaching activity was to motivate learning and raise student commitment. From the questionnaires conducted, students welcomed the peer- teaching activity, and their learning motivation was also improved [4]. The tutor was drawn from a group of higher achievement. According to Boud, Cohen, and Sampson's [12], peer teaching involves students to learn from each friend in a mutually beneficial way that involves sharing knowledge of ideas and experiences among students themselves. Other than that, the student-teachers' peerteaching performance in micro-teaching class at the English Education Department of Universitas Muria Kudus has provided opportunities for students' intensive rehearsals of a teaching simulation to improve their classroom English proficiency [5].

Many programs feature older, more experienced peers, or those with greater mastery in a subject area teaching younger, less-experienced peers or those who are yet to master the subject area's skills and content [6]. Peer tutors must be chosen from students or groups of students who are smarter than their peers so that in the learning process, he can provide enrichment or guide his friends, and he has mastered the material that will be delivered to his friends.

Findings suggest that peer-teaching exercise is found valuable by teacher candidates in that it helps them to increase learning and to be reflective and at the same time it provides the students with the opportunity of self-reflection which later might lead to the development of their teaching and evaluation skills [7].

Another alternative for fostering graduate attributes based on our findings might be to develop a new program of co-curricular peer mentoring, such as senior students peer-reviewing the assignments of junior students [8]. Based on the findings, recommendations are made for faculty members and student service units to implement various types of peer learning to provide 
students with the best possible learning experience [9].

\section{Research Methodology}

Research (CAR) used in this study is to use the Kemmis and McTaggart models. According to [13], the implementation of actions in Classroom Action Research (CAR) includes three paths (steps): (1) action planning; (2) implementing activities and observations; and (3) reflection. The flow (step) of the intended action can be seen in Figure 1.

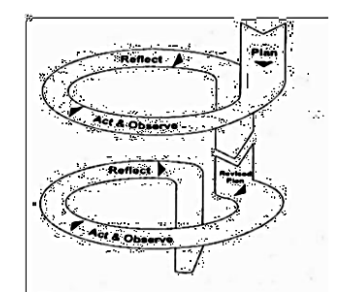

Fig.1. Classroom action research by [13]

Figure 1 shows that first, before acting, the researcher made a plan. Second, after the plan has been carefully prepared, the action is taken, while the action is taking place, the researcher makes observations about implementing the action itself and its consequences. From the observations, researchers then reflect on the actions that have been taken. If the reflection results indicate the need for improvement in the actions taken, then the action plan needs to be refined again so that the actions taken next do not only repeat what has been done before. And so on until the problem under study can be solved optimally.

\section{Discussion}

Pre-action activities are carried out through classroom observations and dialogues with the teacher about drawing clothes, especially the subject matter of drawing the face of an adult woman looking ahead and increasing student learning competence in the learning process. Observation in this pre-cycle is done in one meeting.

Observations were made to determine the learning process of drawing the face of an adult woman looking forward to the method carried out by the teacher. Based on the field notes' results in the pre-cycle learning process, there are still many students who do not understand how to draw faces correctly. It is indicated when the learning process takes place; there are still many students who ask other friends, so that makes the classroom conditions less conducive. The drawing of students in the pre-cycle after being evaluated is that some of the students who have requirement criteria are 20 students from 33 students or $60.6 \%$ with an average grade of 73.90 .

The data obtained on the peer teaching-learning method's application in the first cycle has been carried out following the planning and stages. Although there are still four students who have not yet achieved the KKM value, this learning method is quite capable of increasing student learning competency.

Through this learning method, students are given the maximum opportunity to demonstrate their abilities without extra help from the teacher (for group members). In addition, there is an 
increase in interaction between teachers and students. Student members and tutors have quite a positive impact on learning activities. It can be seen from the acquisition of affective domains in 5 domains that are receiving (responding), responding (responding), assessing (valuing), organization (organization), and characterization (characterization) in the first cycle, which is categorized as high and very high.

Further, the quality of learning is higher in the second cycle specified in the plan. One of the improvements made was to provide guidance, explanation, and additional training for tutors so that the members were more confident in their abilities. Based on data obtained in the second cycle Required for student learning competencies, as evidenced by the number of students who have reached the KKM value of $100 \%$.

Table 1. Relative Frequency Distribution of 33 Pre-Cycle Student Grades

\begin{tabular}{cccc}
\hline No & Interval Class & Frequency & Relatively (\%) \\
\hline 1 & $62-69$ & 7 & 21.21 \\
2 & $70-77$ & 13 & 39.39 \\
3 & $78-85$ & 13 & 39.39 \\
4 & $86-93$ & 0 & 0 \\
\hline
\end{tabular}

Table 1 shows that students who score between 62 and 69 are 7 or $21.21 \%$, while students who score between 70 and 77 are 13 or $39.39 \%$, and students who score between 78 and 85 are 13 or $39.39 \%$. Based on the KKM provisions in Vocational High School (SMK N6 Yogyakarta), students who have achieved the KKM score are 20 students, while those who have not reached the KKM score are 13 students. The results of these student scores indicate that learning has not been attained to the maximum, this can be seen from the number of students who achieved the KKM score of only 20, other than that there were no students who achieved grades between 86 to 93 . Categories of student completeness in the pre-cycle presented in Table 2.

Table 2. Pre-Cycle Completeness Category

\begin{tabular}{cccc}
\hline No & Category & Frequency & Percentage \\
\hline 1 & Pass & 20 & $60,6 \%$ \\
2 & Fail & 13 & $39,4 \%$ \\
& Total & 33 & $100 \%$ \\
\hline
\end{tabular}

Table 3. Relative Frequency Distribution of 33 Cycle I Students

\begin{tabular}{cccc}
\hline No & Interval Class & Frequency & Relatively (\%) \\
\hline 1 & $62-69$ & 0 & 0 \\
2 & $70-77$ & 5 & 15.15 \\
3 & $78-85$ & 25 & 75.76 \\
4 & $86-93$ & 3 & 9.09 \\
\hline
\end{tabular}

Table 3 shows that students who score between 70 and 77 there are five students or $15.15 \%$, while students who score between 78 and 85 there are 25 students or $75.76 \%$, and students who score between 86 and 93 there are three students or $9.09 \%$. Based on the KKM provisions in SMK 6 Yogyakarta, students who have achieved the KKM score are 29 students, while those who have not reached the KKM score are four students.

These data it can be seen that the drawing competence of adult female faces looks aheadin cycle I the percentage of the number of unfinished students decreases by $39.4 \%$ (13\% (13 students) to $12.1 \%$ (4 students) in cycle I. Based on at the first cycle of 33 students, 29 students 
reached the value of the minimum completeness criteria. However, there are still four students who have not yet reached the minimum completeness criteria. The following categories of student's completeness in the first cycle can be seen in Table 4.

Table 4. Mastery Category Cycle I Students

\begin{tabular}{cccc}
\hline No & Category & Frequency & Percentage \\
\hline 1 & Pass & 29 & $87,9 \%$ \\
2 & Fail & 4 & $12,1 \%$ \\
& Total & 33 & $100 \%$ \\
\hline
\end{tabular}

The average value in the first cycle is 81.53 , the highest value is 86.36 , and the lowest value is 73.03 . completeness of learning from pre-cycle to cycle, I increased by $27.3 \%$ from $60.6 \%$ to $87.9 \%$ while the average value increased by $9.36 \%$ from 73.90 to 81.53 . the results above indicate an increase in student learning competence in the first cycle compared to the pre-cycle.

Table 5. Relative Frequency Distribution of Value 33 Cycle II Students

\begin{tabular}{cccc}
\hline No & Interval Class & Frequency & Relatively (\%) \\
\hline 1 & $62-69$ & 0 & 0 \\
2 & $70-77$ & 0 & 0 \\
3 & $78-85$ & 0 & 0 \\
4 & $86-93$ & 33 & 100 \\
\hline
\end{tabular}

Table 5 shows that all students get grades between 86 to 93; there are 33 students or $100 \%$. Based on the KKM provisions in Vocational High School (SMK N6 Yogyakarta), the students who have achieved the KKM score are 33 students or $100 \%$. Based on the data above, it can be seen that the students' learning competence in drawing the face of an adult woman looks ahead of the second cycle. Thirty-three students have been able to achieve the KKM value that has been determined; the data can be seen in Table 6 .

Table 6. Category Minimum Completeness Criteria Cycle II

\begin{tabular}{cccc}
\hline No & Category & Frequency & Percentage \\
\hline 1 & Pass & 33 & $100 \%$ \\
2 & Fail & 0 & $0 \%$ \\
& Total & 33 & $100 \%$ \\
\hline
\end{tabular}

The second cycle's average value is 89.61 , the highest and lowest value is 91.20 , and the lowest value is 86.77 . Mastery learning from cycle I to cycle II increased by $12.1 \%$ from $87.9 \%$ to $100 \%$. The average value increased by $9.02 \%$ from 81.53 to 89.61 . The results above indicate an increase in student learning competence in cycle II compared to cycle I. The increase in incompetence is determined from the increase in student learning completeness.

This first cycle research was conducted in one meeting with an allocation of time of $2 \times 45$ minutes or 90 minutes. The stages begin with planning, acting and observing, and reflecting. By reviewing the results of observations and problems encountered during the action that took place in the first cycle, the data obtained that students are enthusiastic and have the spirit of cooperation in following this learning.

However, they still can not immediately understand the Peer Teaching learning method. There are several weaknesses faced when this first cycle is implemented, including (1) The time is not well managed so that the implementation tends to be rushed; (2) There are some 
students who make noise when in groups and complete the assignments given by the teacher. This is because students are still confused with the process of implementing the Peer Teaching learning method, and (3) Some students who act as tutors are hesitant and are not confident in delivering the material, so repetition is needed in explaining so that group members can understand what is conveyed.

In the first cycle with applying the Peer Teaching learning method to adult women's face drawing material, the front face has increased according to the completeness criteria limit, which is $75 \%$ of all students achieving the specified KKM value. However, because some students have not yet reached the KKM score limit, to convince and strengthen that the Peer Teaching method can improve student learning competencies, teachers and researchers agree to repeat and continue in the second cycle. The results of the reflection, the researcher, together with the observer and the teacher concluded that learning through the Peer Teaching learning method on the drawing material of the face of an adult woman looking forward can improve student learning competence. According to the criteria for the success of the action to be achieved, there is an increase in the second cycle.

Achievement of student learning competencies is better than previously shown from the results of student competencies that have met the minimum completeness criteria that have reached $100 \%$. The action research is not continued in the next cycle. This research has been categorized as successful. Data on student learning competency results are obtained from observation sheets to find out the affective domain of student learning competencies viewed from five domains, namely attending, responding, valuing, organization, and characterization, the cognitive domain is seen based on grades obtained by students through multiple-choice tests, while for the psychomotor domain viewed based on grades achieved by students through the performance assessment sheet. The assessment calculation can be seen in the appendix. The scores obtained by each student are processed into the final value of student learning competencies with an affective real weight of $10 \%$, a cognitive domain of $30 \%$, and a psychomotor domain of $60 \%$.

The minimum completeness criteria that have been set show that 33 students who participated in drawing face learning for adult women in the front view using the teacher's method showed that there were 20 students complete, and 13 students were incomplete. This shows that student learning competency is still low. After being given the action of applying the teaching method of peer teaching, the number of students who completed their learning increased to 29 students, and four students who had not yet completed their studies.

After taking action, the application of the peer teaching-learning method in cycle II increased. It is proven that the number of students who score below KKM does not exist (100\%). From 33 students in the first cycle, the number of students who completed their study is 29 students then after being subjected to action in the second cycle, the number of students who completed their study increased to 33 students.

Whereas for students who did not complete in cycle I, there were four students, then after being subjected to action in cycle II the number of students who did not complete did not exist. It can be concluded that this peer teaching-learning method can improve student learning competencies. So the teacher and researcher decide to end the action in the second cycle because this research can be said to be successful. Following is the comparison of students' completeness starting from pre-cycle, cycle I, and cycle II. 


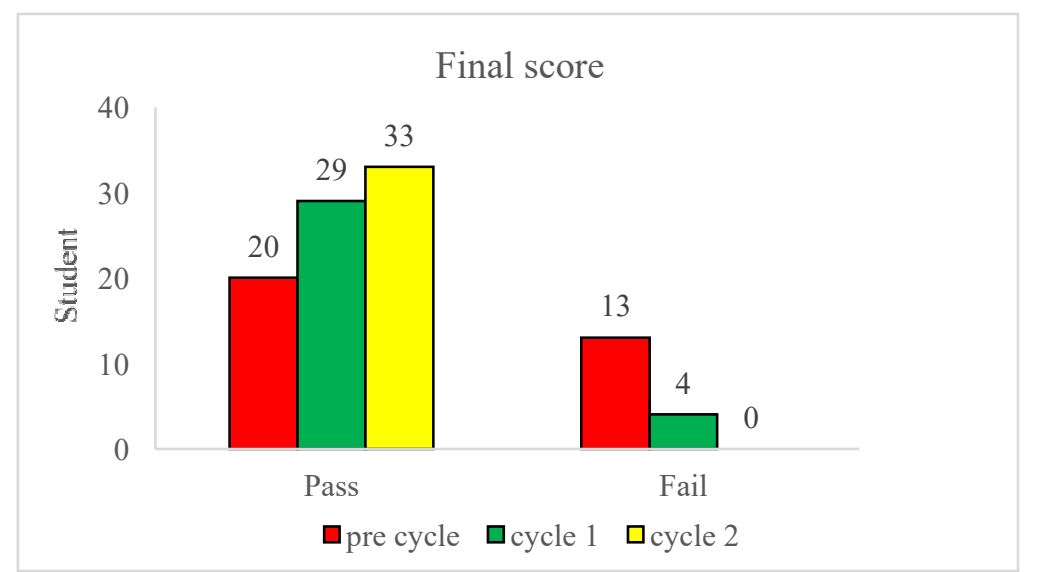

Fig.2. The category of pre-cycle final value acquisition, cycle I, and cycle II

Figure 2 shows that the learning drawing of the face of an adult female front looks increased after taking action by applying the method of peer teaching-learning to improve student learning competence. It was proven from the pre-cycle results that only 20 students had achieved the KKM value, then after taking action in cycle I, It had increased $31 \%$, from $(60.6 \%) 20$ students who had achieved the KKM value to (87.9\%) 29 students who had achieved the KKM value. After taking action in cycle II, completeness learning from cycle I to cycle II increased by $12.1 \%$ from $87.9 \%$ (29 students) to $100 \%$ (33 students) achieving the KKM value. An increase in student learning competence in each cycle carried out indicates the success of the action [14].

\section{Conclusion}

The application of the Peer Teaching learning method is carried out in 2 cycles. Starting from the Preliminary stage, learning Implementation Stage, starting from the teacher arranging a learning group consisting of tutors and members with diverse abilities. The teacher explains the task's completion with the peer teaching method and determines work rules for the tutors. The teacher explains the material, gives assignments along with a worksheet, the tutors are responsible responsibility to accompany members, during the activity the teacher gives control to avoid mistakes and supervise and assess students 'attitudes according to the observation sheet from the researcher after the tutor has finished gathering the members' assignments and handed over to the teacher. Closing Stage, the first is done by the teacher, which concludes the subject matter and evaluates the teacher, tutor, and students' learning process.

Increased student learning competence is very significant, seen from the results of the first cycle increased $31 \%$, from (60.6\%) 20 students who achieved the KKM value to $(87.9 \%) 29$ students who achieved the KKM value. Then after taking action in cycle II, completeness learning from cycle I to cycle II increased by $12.1 \%$ from $87.9 \%$ (29 students) to $100 \%$ (33 students) achieving the KKM value. 


\section{References}

[1] Farachala, C., et al.: Miren: Bridging between Action Research Communities: A Pathway to Connectivity, IJAR-International Journal of Action Research. pp. 5-22 (2020).

[2] Carrillo, T, Alfonso: Another social research is possible. From the Collaboration Between Researchers and Social Movements. IJAR - International Journal of Action Research. pp. 23-39 (2020).

[3] Webera, S., Harris, R.: „Now I can be a Poetic Writer’: Using Action Research as a Way Of Reclaiming And Implementing Professional Values in the Primary School. Educational Action Research. Pp. (2020).

[4] Lim, L.L.: A Case Study on Peer-Teaching. Open Journal of Social Sciences. pp. 35-40 (2014).

[5] Rokhayani, A., et al.: Peer Teaching as a Simulation for Communicative Classroom English Rehearsal. Celt: A Journal of Culture, English Language Teaching and Literature, pp. 103 - 116 (2017).

[6] Kim Bradford-Watts. Students Teaching Students? Peer teaching in the EFL Classroom in Japan. The Language Teacher Online. (2011).

[7] Kavanoz, H.S., Yüksel, G.: An Investigation of Peer-Teaching Technique in Student Teacher Development. Educational Research Association The International Journal of Research in Teacher Education. pp. 0-19 (2010).

[8] Scott, C.A., McLean, A., Golding, C.: How Peer Mentoring Fosters Graduate Attributes. Journal of Peer Learning. pp. 29-44 (2019).

[9] Zhang, Z., Bayley, J.G.,: Peer learning for University Students' Learning Enrichment: Perspectives of Undergraduate Students. Journal of Peer Learning. pp. 61-74 (2019).

[10] Howe E., Ruberg, A.: Digipen: Secondary School Project - Based Learning in Game Design,Digital Arts And Life Skills. Canadian Journal of Action Research. pp. 28-47 (2020).

[11] Zainal A.: Penelitian Pendidikan. Bandung: PT. Remaja Rosdakarya (2011). (In Indonesian).

[12] Endang M.: Riset Terapan. Yogyakarta: UNY Press (2011). (In Indonesian).

[13] Pardjono, dkk.: Panduan Penelitian Tindakan Kelas. Yogyakarta: Lembaga Penelitian UNY (2011). (In Indonesian).

[14] Sri Waluyanti : Meningkatkan Kompetensi Pedagogi dan Vokasional melalui Metode Peer Teaching dan Kooperatif Jigsaw pada Mata Kuliah Sistem Video. Jurnal Pendidikan Teknologi dan Kejuruan. Vol 19, No 1 (2010). 